\title{
Analysis and characterization of a japanese garden in Ribeirão Preto (SP), Brazil (1)
}

\author{
MARCOS VIEIRA FERRAZ (2); CAMILA JUNQUEIRA FERNANDES (3); \\ DAVID LUCIANO ROSALEN('(3); RENATA GIMENES ${ }^{(3)}$; GUSTAVO DE NÓBREGA ROMAN(I); \\ CLAUDIA FABRINO MACHADO MATTIUZZ ${ }^{(4)}$; KATHIA FERNANDES LOPES PIVETTA ${ }^{(3)}$;
}

\begin{abstract}
The Japanese Garden of the Fábio Barreto Municipal Forest/Zoo in Ribeirão Preto, state of São Paulo, Brazil, was analyzed. Among the vegetation elements, 362 individuals (trees and shrubs) were identified, covering 80 species, 69 genera and 41 families. The Shannon-Weaver biodiversity index of the area was 3.48. Many plants (50\%) are not of Asian origin, mischaracterizing the garden. Some elements such as the pagoda, a stone lamp, Mount Fuji and the bridges to the island in the center of one of the lakes were according with the philosophy of a Japanese garden; however, other aspects like commemorative plates, trash containers and concrete benches were uncharacteristic. The survey conducted to know the visitor profile and value for local respondents concluded that most visitors have high school education (42\%), are women (52\%) or are between 41 and 60 years old (44\%). Most (88\%) are unaware of the principles that guide the Japanese garden style. The style of the garden is not fully characteristic and showed maintenance problems.
\end{abstract}

Keywords: landscaping, garden style, oriental garden

\section{RESUMO}

Análise e caracterização de um jardim japonês em Ribeirão Preto (SP), Brasil

Foi feita uma análise do jardim japonês do Bosque/Zoo Municipal Fábio Barreto de Ribeirão Preto, São Paulo, Brasil. Entre os elementos vegetais, foram levantados 362 indivíduos (arbóreos e arbustivos), distribuídos em 80 espécies, 69 gêneros e 41 famílias botânicas. A área estudada apresentou índice de biodiversidade de Shannon-Weaver de 3,48. Grande parte das plantas não é de origem asiática, descaracterizando o jardim. Alguns elementos como o pagode, a luminária de pedra, o Monte Fuji e as pontes para as ilhas no centro de um dos lagos estavam de acordo com a filosofia do jardim japonês; no entanto, outros, como placas comemorativas, lixeiras e bancos de concreto não eram característicos. Na pesquisa de opinião realizada para se conhecer o perfil do visitante e a importância do local para os entrevistados, concluiu-se que a maioria possui ensino médio (42\%) e é constituída de mulheres (52\%) entre as idades de 41 e 60 anos (44\%). A maioria (88\%) desconhece os princípios que norteiam o estilo de jardim japonês. O jardim encontra-se descaracterizado quanto ao estilo e apresenta problemas de manutenção.

Palavras-chave: paisagismo, estilo de jardim, jardim oriental

\section{INTRODUCTION}

The Japanese garden has captured the imagination of Western gardeners ever since they discovered its delights in the $19^{\text {th }}$ century. Japan, isolated from the rest of the world after the 1630s for over 200 years, had been nurturing extraordinary and unique styles of architecture, poetry, painting, flower arranging and gardening (CHESSHIRE, 2011a).

One of the extraordinary aspects of looking at Japanese gardens today is that we can feel a common bond with garden creators of 1,000 years ago (KETCHELL, 2005). Japanese gardens intend to absorb ambience and feelings from nature, using imagination to recreate the same mood in the garden (SAWANO, 2008). A Japanese garden should present key elements in any location where it is deployed; otherwise, it ceases to be a Japanese garden and becomes a symbolic representation.

Some elements are essential in a Japanese garden, as follows.
A) Camellia, said to be special because Buddha died beneath a pair of such trees (GONG and PARRAMORE, 2006).

B) Pine, from the earliest times considered to be the "king" of garden plants and believed to bring good fortune. There are many different varieties of pine found worldwide. Black pine, for example, is strong and bold, while white pine has a more gentle and noble air (SAWANO, 2008). They are symbol of endurance (YOUNG e YOUNG, 2005).

C) Sakura. It is because of the sakura, or cherry blossom, that Japanese gardens have become famous the world over. Before the $19^{\text {th }}$ century these trees were object of veneration and celebration, their short-lived blossom being viewed by the samurai as a reminder of their own fragile mortality, and a symbol of chivalry and loyalty to their lords and masters (CHESSHIRE, 2011b).

D) Stone lanterns, originally used to light the front of Buddhist temples and made of bronze, frequently with elaborate ornamentation (UNDERWOOD, 2005), and later, Shinto shrines, where they were used in one of two ways (and still are today) (KEANE, 2009).

(1) Recebido em 17/09/2015 e aceito em 28/11/2015

(2) Universidade Estadual Paulista (UNESP), FCA, Botucatu-SP, Brazil. Corresponding author: ferrazmarcos@yahoo.com.br

(3) Universidade Estadual Paulista (UNESP), FCAV, Jaboticabal-SP, Brazil.

(4) Universidade de São Paulo (USP), ESALQ, Piracicaba-SP. Brazil. 
The quality of a Japanese garden depends on the plants (HORTON, 2003). Authentic Japanese gardens and others blended with tropical style are found in Brazil, which can be noted by their architectural features, flora and fauna. Many Brazilian cities have created Japanese gardens in several private and public areas such as parks and squares in honor of Japanese immigrants and descendants; nevertheless, these spaces are not often designed in their proper model and are sometimes mismanaged or even abandoned by people and government bodies. The Japanese Garden in the Fábio Barreto Municipal Forest/Zoo was built by the local government and occupies an area of approximately 20,000 square meters. The garden is decorated with lakes, bridges and characteristic rocks, and the vegetation is composed of seedlings that had been cultivated by the Japanese Colony of Osasco (SP) with seeds from Japan. The opening ceremony took place on June 29, 1969, being part of the program of festivities of the 113th anniversary of Ribeirão Preto (GUIA DOS MONUMENTOS EM LUGARES PÚBLICOS, 2011). Thus, this study aimed to analyze the Japanese Garden in the Fábio Barreto Municipal Forest/ Zoo in Ribeirão Preto, São Paulo State, Brazil, considering the landscape and phytosociological points of view.

\section{MATERIAL AND METHODS}

This survey was performed at the Japanese Garden in the Fábio Barreto Municipal Forest/Zoo in Ribeirão Preto (SP), Brazil. The city is located at $21^{\circ} 12^{\prime} 42^{\prime \prime}$ latitude and $47^{\circ} 48^{\prime} 24^{\prime \prime}$ longitude, $313 \mathrm{~km}$ northwest of the capital São Paulo. Its territory of 651 square kilometers has an estimated population of 612,339 inhabitants (IBGE, 2011).

A planialtimetric and cadastral survey was made of the area covered by the Japanese Garden in the months from October to December 2011. A conventional ray method was applied, using a full station with accessories. For this, we used a Topcon total station, GTS model with angular accuracy of 2 " and linear accuracy of $2 \mathrm{~mm}+2$ $\mathrm{mm}$ per $\mathrm{km}$.

Field observations of the survey were processed in the system, and the final design was elaborated using AutoCAD 2011 topography system. The design was guided by magnetic north according to the Associação Brasileira de Normas Técnicas (ABNT, 1994) standards for technical design and topography. The mapped elements were grouped in layers in order to permit its adequate visualization.

The tree and shrub species were identified by on-site species identification, and their origins in subsequent research, both with the aid of specialized literature (LORENZI and SOUZA, 1996, LORENZI et al., 2003, and LORENZI, 2008, 2009), following the APG II botanical classification (SOUZA and LORENZI, 2008) and Brummitt and Powell (1992) descriptors.

For the calculation of diversity indexes, we applied formulas adapted by Roberts (1998) and Romani (2011):

A) Absolute density (DA): $\mathrm{DA}=\mathrm{Ni} / \mathrm{A}$, Wherein: $\mathrm{Ni}$ $=$ number of individuals of $i$ species and $\mathrm{A}=$ total sampled area $\left(\mathrm{m}^{2}\right)$

B) Relative density (DRI) DRI $=100 \times(\mathrm{NI} / \mathrm{NT})$; Wherein: $\mathrm{Ni}=$ number of individuals of $i$ species and $\mathrm{Nt}=$ total number of individuals

C) Shannon-Weaver index (H'): $\mathrm{H}^{\prime}=$ $\sum^{s}$ Where in: pi $=$ sample ratio with individuals $\sum_{i=1}$ pi ln pi of $i$ species.

Quantification and qualification of the architectural elements and the opinion poll of 100 people were performed on different days of the week and at various times to identify visitor's profile and place importance according to respondents, as well as people's opinion on the place visited. For this purpose, a questionnaire based on those proposed by De Angelis (2000) and De Angelis and De Angelis Neto (1999) was supplied to the visitors.

\section{RESULTS}

Planimetric cadastral survey outcomes can be seen in Figure 1 (map). From the total area of 8,035.4 $\mathrm{m}^{2}, 980.7 \mathrm{~m}^{2}$ are taken up by water surface.

We recorded 362 individuals belonging to 80 species, 


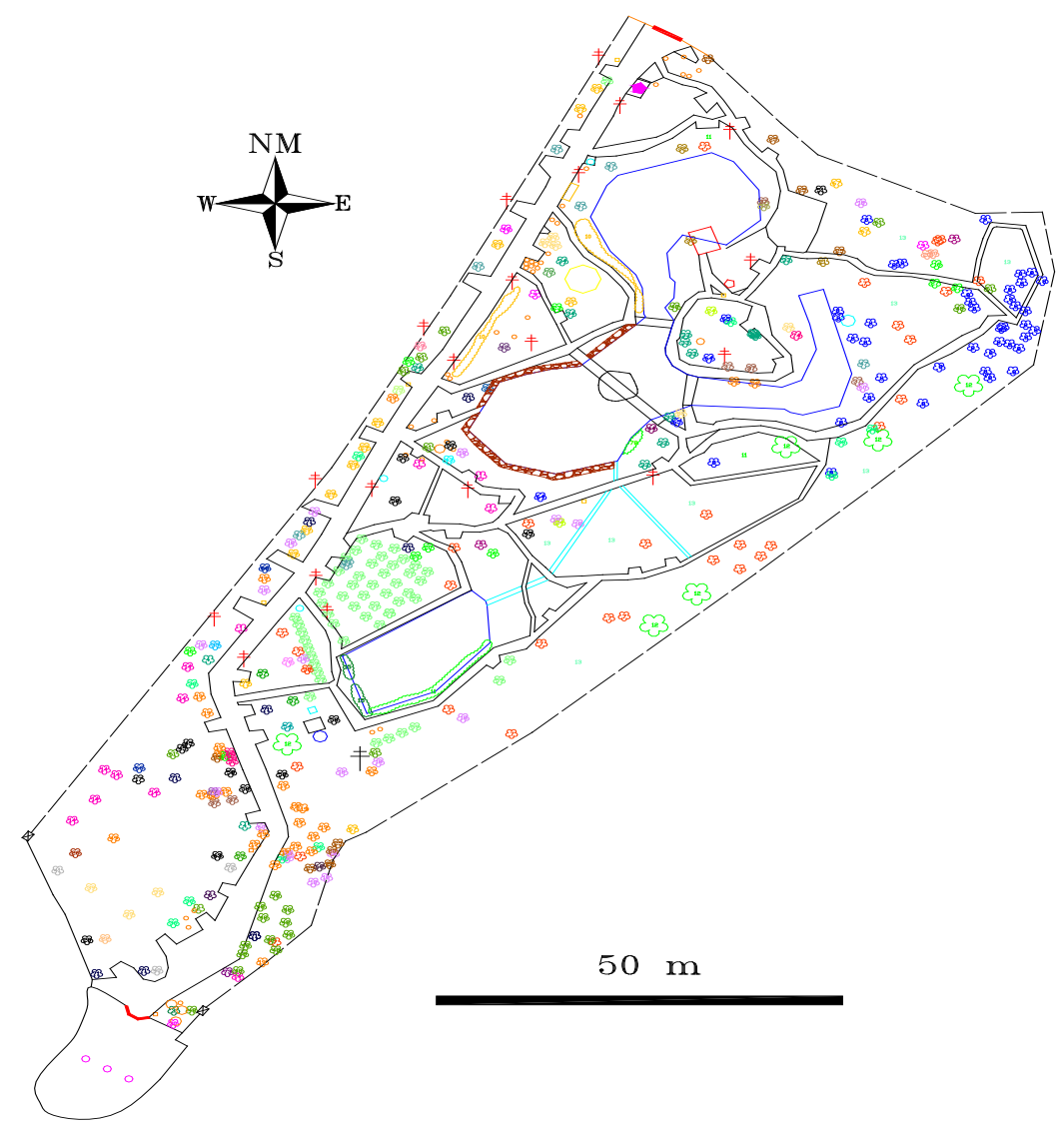

Figure 1. Landscape Map of the Japanese Garden of the Fábio Barreto Municipal Forest/Zoo in Ribeirão Preto (SP) - map (UNESP / NGAP)

Figura 1 Mapa paisagístico do Jardim Japonês do Bosque/Zoológico Municipal Fábio Barreto de Ribeirão Preto (SP) - mapa (UNESP/NGAP)

Table 1. Species classified in botanical families, scientific name, common Brazilian name, origin and total number of individuals (NI)

Tabela 1. Espécies classificadas por família botânica, nome científico, nome vulgar brasileiro, origem e número total de indivíduos (NI)

\begin{tabular}{|c|c|c|c|c|}
\hline Botanical Family & Scientific name & Common name & Origin \\
\hline Poaceae & Phyllostachys viridis & Bambu-de-pescar & Japan & China \\
\hline Ericaceae & Rhododendron simsii & Azaléia & $3 *$ \\
\hline Poaceae & Bambusa gracilis & Bambu-de-jardim & China and Japan & $3 *$ \\
\hline Plumbaginaceae & Plumbago auriculata & Bela-emília & South Africa & $2 *$ \\
\hline Cyperaceae & Cyperus alternifolius & Sombrinha-chinesa & Madagascar & $1 *$ \\
\hline Rutaceae & Murraya paniculata & Murta-de-cheiro & Asiatic & 54 \\
\hline Anacardiaceae & Schinus terebinthifolia & Aroeira & Brazil & 40 \\
\hline Mimosaceae & Anadenanthera macrocarpa & Angico-vermelho & Brazil & 30 \\
\hline Rubiaceae & Coffea arabica & Café & Africa & 25 \\
\hline Fabaceae & Myrocarpus frondosus & Cabreúva & Brazil & 18 \\
\hline Agavaceae & Yucca elephantipes & Yucca & Mexico and Guatemala & 14 \\
\hline Cicadaceae & Cycas revoluta & Cycas-revoluta & Japan and Indonesia & 10 \\
\hline Riscaceae & Dracaena marginata & Dracena-verde & Madagascar \\
\hline Fabaceae & Senna macranthera & Cássia-manduirana & Brazil \\
\hline
\end{tabular}


Table 1. cont.

\begin{tabular}{|c|c|c|c|c|}
\hline Lauraceae & Nectandra megapotamica & Canelinha & Brazil & 9 \\
\hline Arecaceae & Syagrus romanzoffiana & Palmeira-jerivá & Brazil & 8 \\
\hline Musaceae & Musa sp. & Bananeira & Asia & 8 \\
\hline Myrtaceae & Eugenia uniflora & Pitanga & Brazil & 8 \\
\hline Bignoniaceae & Handroanthus impetiginosus & Ipê-roxo & Brazil & 7 \\
\hline Poaceae & Dendrocalamus giganteus & Bambu-gigante & Malasia & 6 \\
\hline Urticaceae & Cecropia purpurascens & Embaúba & Brazil & 6 \\
\hline Malvaceae & Pachira aquatica & Monguba & Brazil & 5 \\
\hline Myrsinaceae & Ardisia crenata & Cafezinho-de-salão & Japan & 5 \\
\hline Agavaceae & Agave attenuata & Tromba-de-elefante & Mexico & 4 \\
\hline Fabaceae & Albizia niopoides & Farinha-seca & Brazil & 4 \\
\hline Malpighiaceae & Malpighia emarginata & Acerola & West Indies & 4 \\
\hline Annonaceae & Rollinia mucosa & Biribá & Brazil & 3 \\
\hline Araliaceae & Aralia excelsa & Carobão & Brazil & 3 \\
\hline Bignoniacea & Tabebuia roseoalba & Ipê-branco & Brazil & 3 \\
\hline Brassicaceae & Crataeva tapia & Pau-d'alho & Brazil & 3 \\
\hline Clusiaceae & Clusia fluminensis & Clúsia & Brazil & 3 \\
\hline Lecythidaceae & Cariniana legalis & Jequitibá-vermelho & Brazil & 3 \\
\hline Anacardiaceae & Astronium fraxinifolium & Aroeira-rosa & Brazil & 2 \\
\hline Anacardiaceae & Mangifera indica & Mangueira & Asia & 2 \\
\hline Arecaceae & Ptychosperma elegans & Palmeira-elegante & Australia & 2 \\
\hline Arecaceae & Phoenix roebelenii & Palmeira-phoenix & $\begin{array}{l}\text { Vietnam, Assam and } \\
\text { Cochinchina }\end{array}$ & 2 \\
\hline Arecaceae & Rhapis excelsa & Palmeira-ráphis & China & 2 \\
\hline Bombacaceae & Ceiba boliviana & Paineira-rosa & Brazil & 2 \\
\hline Caricaceae & Carica papaya & Mamoeiro & Mexico & 2 \\
\hline Fabaceae & Holocalyx balansae & $\begin{array}{l}\text { Alecrim-de- } \\
\text { campinas }\end{array}$ & Brazil & 2 \\
\hline Fabaceae & Pterogyne nitens & Amendoim-bravo & Brazil & 2 \\
\hline Fabaceae & Cassia ferruginea & Canafístula & Brazil & 2 \\
\hline Malvaceae & Sterculia chicha & Chichá & Brazil & 2 \\
\hline Rubiaceae & Genipa americana & Jenipapo & Tropical America & 2 \\
\hline Acanthaceae & Aphelandra squarrosa & Afelandra & Brazil & 1 \\
\hline Acanthaceae & Pachystachys lutea & Camarão-amarelo & Peru & 1 \\
\hline Agavaceae & Agave angustifolia & Agave & West Indies and Mexico & 1 \\
\hline Amarilidaceae & Furcraea gigantea & Piteira & Brazil & 1 \\
\hline Anacardiaceae & Spondias cythera & Cajamanga & Asia & 1 \\
\hline Anacardiaceae & Astronium graveolens & Guaritá & Brazil & 1 \\
\hline Anacardiaceae & Spondias purpurea & Seriguela & South and Central America & 1 \\
\hline Apocynaceae & Plumeria rubra & Leitoso & Tropical America & 1 \\
\hline Apocynaceae & Geissospermum laeve & Pau-pereira & Brazil & 1 \\
\hline Apocynaceae & Aspidosperma cylindrocarpon & Peroba-rosa & Brazil & 1 \\
\hline Arecaceae & Caryota urens & Palmeira-cariota & $\begin{array}{c}\text { Malasia,India and Asiatic } \\
\text { Southeast }\end{array}$ & 1 \\
\hline Arecaceae & Roystonea oleracea & Palmeira-imperial & West Indies & 1 \\
\hline Bignoniaceae & Handroanthus avellanedae & Ipê-rosa & Brazil & 1 \\
\hline Ebenaceae & Diospyros kaki & Caqui & China & 1 \\
\hline Euphorbiaceae & Euphorbia leucocephala & Leiteiro & Central America & 1 \\
\hline Fabaceae & Cassia fistula & Cássia-imperial & Asia & 1 \\
\hline
\end{tabular}


Table 1. cont.

\begin{tabular}{|c|c|c|c|c|}
\hline Fabaceae & Cassia grandis & Cássia-rosa & Brazil & 1 \\
\hline Fabaceae & Guibourtia hymenaefolia & Jatobá & Brazil & 1 \\
\hline Fabaceae & Lonchocarpus campestris & Sapulva & Brazil & 1 \\
\hline Ginkgoaceae & Ginkgo biloba & Ginkgo-biloba & China & 1 \\
\hline Heliconiaceae & Heliconia rostrata & Helicônia & Brazil & 1 \\
\hline Lecythidacea & Cariniana estrellensis & Jequitibá-branco & Brazil & 1 \\
\hline Malpighiaceae & Bunchosia armeniaca & Falso-guaraná & Colombia & 1 \\
\hline Malvaceae & Sterculia striata & Sapucaia & Brazil & 1 \\
\hline Melastomataceae & Tibouchina granulosa & Quaresmeira & Brazil & 1 \\
\hline Moraceae & Ficus guaranitica & Figueira & Brazil & 1 \\
\hline Moraceae & Ficus dendrocida & Figueira-branca & Brazil & 1 \\
\hline Myrtaceae & Eugenia tomentosa & Cabeludinha & Brazil & 1 \\
\hline Nyctaginaceae & Bougainvillea spectabilis & Primavera & Brazil & 1 \\
\hline Pinaceae & Pinus thunbergii & Pinheiro-japonês & North Hemisphere & 1 \\
\hline Riscaceae & Dracaena bicolor & Dracena-brasileira & Madagascar & 1 \\
\hline Rosaceae & Morus sp. & Amora & Asiatic & 1 \\
\hline Rosaceae & Prunus serrulata & Cerejeira-do-japão & Asia & 1 \\
\hline Rutaceae & Citrus sp. & Limoeiro & Asia & 1 \\
\hline Rutaceae & Citrus reticulata & Tangerina & Asia & 1 \\
\hline Theaceae & Camellia japonica & Camélia & Japan, China and Corea & 1 \\
\hline
\end{tabular}

*Macico

69 genera and 41 families. Of the total amount, 40 species are exclusively of Brazilian origin.

Rutaceae was the family with the highest number of individuals with all species of Asian origin. Rutaceae,
Anacardiaceae and Fabaceae families accounted for 39.9\% of total species. Table 2 shows phytosociological parameters calculated through the obtained data.

Considering relative density of the species (Table 2),

Table 2. Phytosociological Descriptors: N - number of individuals; DA - absolute density; DR - relative density Tabela 2. Descritores fitossociológicos: N - número de indivíduos; DA - densidade absoluta; DR - densidade relativa

\begin{tabular}{|l|c|c|c|}
\hline Nome Cientifico & NI & DA & DR \\
\hline Agave angustifolia & 1 & 0.000124 & 0.276243 \\
\hline Agave attenuata & 4 & 0.000498 & 1.104972 \\
\hline Albizia niopoides & 4 & 0.000498 & 1.104972 \\
\hline Anadenanthera macrocarpa & 30 & 0.003733 & 8.287293 \\
\hline Aphelandra squarrosa & 1 & 0.000124 & 0.276243 \\
\hline Aralia excelsa & 3 & 0.000373 & 0.828729 \\
\hline Ardisia crenata & 5 & 0.000622 & 1.381215 \\
\hline Aspidosperma cylindrocarpon cylindrocarpon & 1 & 0.000124 & 0.276243 \\
\hline Astronium fraxinifolium & 2 & 0.000249 & 0.552486 \\
\hline Atronium graveolens & 1 & 0.000124 & 0.276243 \\
\hline Bougainvillea spectabilis & 1 & 0.000124 & 0.276243 \\
\hline Bunchosia armeniaca & 1 & 0.000124 & 0.276243 \\
\hline Camellia japonica & 1 & 0.000124 & 0.276243 \\
\hline Carica papaya & 2 & 0.000249 & 0,552486 \\
\hline Cariniana estrellensis & 1 & 0.000124 & 0.276243 \\
\hline Cariniana legalis & 3 & 0.000373 & 0.828729 \\
\hline Caryota urens & 1 & 0.000124 & 0.276243 \\
\hline Cassia ferruginea & 2 & 0.000249 & 0.552486 \\
\hline Cassia fistula & 1 & 0.000124 & 0.276243 \\
\hline Cassia grandis & 1 & 0.000124 & 0.276243 \\
\hline Cecropia purpurascens & 6 & 0.000747 & 1.657459 \\
\hline Ceiba boliviana & 2 & 0.000249 & 0.552486 \\
\hline
\end{tabular}


Table 2. cont.

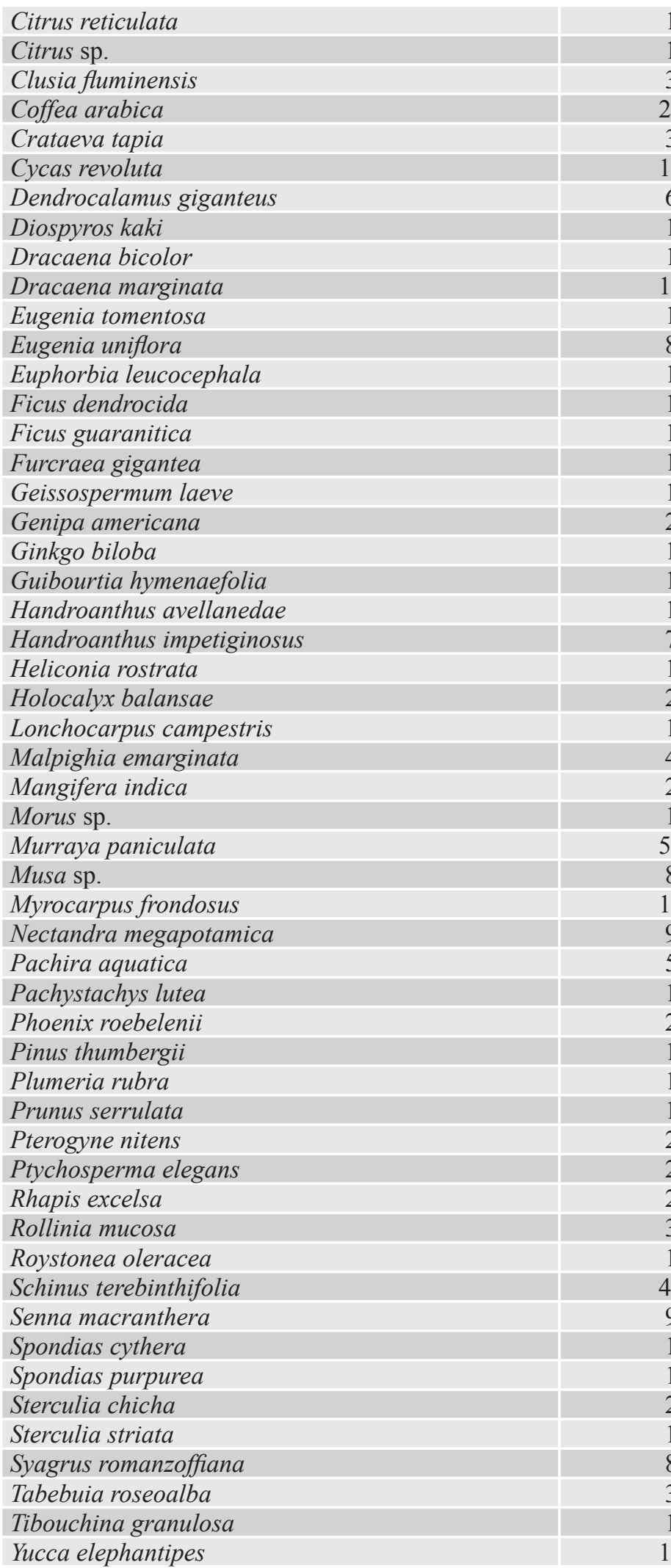

\begin{tabular}{|c|c|c|}
\hline 1 & 0.000124 & 0.276243 \\
\hline 1 & 0.000124 & 0.276243 \\
\hline 3 & 0.000373 & 0.828729 \\
\hline 25 & 0.003111 & 6.906077 \\
\hline 3 & 0.000373 & 0.828729 \\
\hline 10 & 0.001244 & 2.762431 \\
\hline 6 & 0.000747 & 1.657459 \\
\hline 1 & 0.000124 & 0.276243 \\
\hline 1 & 0.000124 & 0.276243 \\
\hline 10 & 0.001244 & 2.762431 \\
\hline 1 & 0.000124 & 0.276243 \\
\hline 8 & 0.000996 & 2.209945 \\
\hline 1 & 0.000124 & 0.276243 \\
\hline 1 & 0.000124 & 0.276243 \\
\hline 1 & 0.000124 & 0.276243 \\
\hline 1 & 0.000124 & 0.276243 \\
\hline 1 & 0.000124 & 0.276243 \\
\hline 2 & 0.000249 & 0.552486 \\
\hline 1 & 0.000124 & 0.276243 \\
\hline 1 & 0.000124 & 0.276243 \\
\hline 1 & 0.000124 & 0.276243 \\
\hline 7 & 0.000871 & 1.933702 \\
\hline 1 & 0.000124 & 0.276243 \\
\hline 2 & 0.000249 & 0.552486 \\
\hline 1 & 0.000124 & 0.276243 \\
\hline 4 & 0.000498 & 1.104972 \\
\hline 2 & 0.000249 & 0.552486 \\
\hline 1 & 0.000124 & 0.276243 \\
\hline 54 & 0.006720 & 14.917127 \\
\hline 8 & 0.000996 & 2.209945 \\
\hline 18 & 0.002240 & 4.972376 \\
\hline 9 & 0.001120 & 2.486188 \\
\hline 5 & 0.000622 & 1.381215 \\
\hline 1 & 0.000124 & 0.276243 \\
\hline 2 & 0.000249 & 0.552486 \\
\hline 1 & 0.000124 & 0.276243 \\
\hline 1 & 0.000124 & 0.276243 \\
\hline 1 & 0.000124 & 0.276243 \\
\hline 2 & 0.000249 & 0.552486 \\
\hline 2 & 0.000249 & 0.552486 \\
\hline 2 & 0.000249 & 0.552486 \\
\hline 3 & 0.000373 & 0.828729 \\
\hline 1 & 0.000124 & 0.276243 \\
\hline 40 & 0.004978 & 11,049724 \\
\hline 9 & 0.001120 & 2.486188 \\
\hline 1 & 0.000124 & 0.276243 \\
\hline 1 & 0.000124 & 0.276243 \\
\hline 2 & 0.000249 & 0.552486 \\
\hline 1 & 0.000124 & 0.276243 \\
\hline 8 & 0.000996 & 2.209945 \\
\hline 3 & 0.000373 & 0.828729 \\
\hline 1 & 0.000124 & 0.276243 \\
\hline 14 & 0.001742 & 3.867403 \\
\hline
\end{tabular}


Murraya paniculata (Rutaceae) and Schinus terebinthifolia (Anacardiaceae) were the most representative, depicting $14.9 \%$ and $11 \%$ of the total amount, respectively; however, the other species did not exceed 10\% (Table 2).

The Shannon-Weaver index (H') of the Japanese Garden reached the value of 3.48 .

Only one specimen was observed of the Japanese cherry (Prunus serrulata). Moreover, we found three species of Asian bamboos. We also found the following architectural elements: three lakes, two water channels, 1 concrete lamppost, 19 iron poles, 4 bridges, 7 wastebaskets, 3 flag masts, 1 tea house, 1 Mount Fuji, 3 taps, 1 island, 39 concrete benches, 1 pagoda, one shrine gateway, 1 stone lantern, one light box, 2 boxes of water and 1 gazebo.

Visiting frequency varied among age groups. The highest frequency occurred for people of 41-60 years old (44\%), followed by $21-40$ years of age (34\%), $0-20$ years $(12 \%)$, and more than sixty years $(10 \%)$.

Education level varied among groups of respondents, being $42 \%$ secondary, $32 \%$ higher and $26 \%$ elementary. In addition, as a result of the survey, $74 \%$ knew the name of the type of garden (Japanese Garden) by the time they were asked about it, $88 \%$ did not know the history of this Japanese garden before visiting the place, and 32\% did not know about the existence of a Japanese Garden in the city before visiting the Fábio Barreto Municipal Forest/ Zoo. When the visitors were asked about the quality of the garden, $40 \%$ replied that it had improved over the years, and for $24 \%$ it had worsened.

Regarding visitors' profile, it can be stated that adults visit more frequently than young people, and the garden is equally visited by men (48\%) and women $(52 \%)$. The reason for people to visit the Japanese garden were taking a child (34\%), resting (16\%), walking (12\%), sunbathing, reading and playing sports $(<1 \%)$ and others $(38 \%)$.

About respondent occupation, it was assessed that $70 \%$ were employed, $18 \%$ were retired, $6 \%$ were students and $6 \%$ were housewives. Unemployed people were not identified.

\section{DISCUSSION}

Currently, the Japanese Garden covers $40.18 \%$ of its original area, which was initially $20,000 \mathrm{~m}^{2}$, as had been reported at the opening in 1969 (GUIA DOS MONUMENTOS EM LUGARES PÚBLICOS, 2011). A likely explanation for this reduction of $59.82 \%$ in initial area is that the zoo needed more area to improve its animal installations.

A great number of Brazilian native species was observed, pointing at insufficient expertise to manage this type of garden (Table 1). In Japanese gardens, plant species are chosen due to the underlying philosophy of their place of origin.

Although it is important to use oriental flora species in such gardens, the use of native species is technically recommended, mainly to ensure ecological relationships and co-evolutionary genetic dispersal propagules (pollen and seeds) involving flora and fauna within the urban environment and for conservation of indigenous genetic material (PAIVA et al., 2010).

Aiming to maintain a great diversity of plants in urban forestry as a whole, Santamour Júnior (1990) considered that the relative density of plants shall not exceed a maximum of $10 \%$. The author asserted that a large variety of tree species in urban landscapes is required to ensure plant health with regard to pest and diseases. Then, it is not recommended to exceed $10 \%$ per species, $20 \%$ per genus and $30 \%$ per family. Additionally, other authors, including Grey and Deneke (1986) and Milano and Dalcin (2000), asserted that each species should not exceed $15 \%$ of the individuals in the arboreal population for good planning of urban vegetation. The Japanese Garden in this study is in accordance with the authors' recommendations and close to what Santamour Junior (1990) suggested.

The Shannon-Weaver index is mostly used to measure the floristic diversity (CAMPOS et al., 2000); it takes into account the number of species (species richness) and the uniformity of distribution of the species (ratio) (PINTOCOELHO, 2000).

Some other studies conducted in urban areas have calculated the Shannon-Weaver index (H'). Romani (2012), analyzing the XV de Novembro Square in Ribeirão Preto (SP), obtained a value of 3.14 for the same index. Bortoleto et al. (2007), analyzing urban trees of the tourist city of Águas de São Pedro (SP), obtained a value of 3.90. These values were considered good by the authors.

By analyzing the number of species, the relative density and the work carried out in the urban area, squares and roads only, a diversity index of 3.48 is considered a good value.

Other architectural elements, such as Mount Fuji, statue, commemorative plaques, concrete benches, or are in disrepair or not representing Japanese culture.

Roderjan and Barddal (1998) commented that the rich and diverse landscape of a large urban space destined to an intense movement of people guarantees an environment where there are ecological, social and economic benefits.

Despite having a large number of native species that interfere in the garden's authenticity, the analyzed area has a great floristic diversity.

Therefore, to improve the garden's plant diversity and style authenticity, some of the native species should be replaced by species of Asian origin, which have already been adapted to the local conditions, such as Syngonium angustatum.

Cherry blossom, e.g. Prunus serrulata, is considered Japan's national flower and has been admired by Japanese people for over 1,500 years. In the Muromachi period (1336 - 1573) the cherry tree was considered the meeting place between life and death (LEVY-YAMAMORI and TAAFFE, 2004).

Keane (1996) commented that pine, bamboo and plum are a classic Japanese trio and are always represented in paintings, symbolizing three good things in descending order: the best, the great and the good. However, there is no plum in the Japanese Garden in the Fábio Barreto Municipal Forest/Zoo of Ribeirão Preto.

Regarding the architectural elements, the gateway, stone 
lantern, pagoda and bridges, they are in good condition and characterize this style of garden. The other elements are either broken or do not represent genuinely the Japanese gardening and landscaping design.

The Japanese garden has a peculiar feature to be as natural as possible. The cascade that is present in this garden appears to be natural; however, the stones are visibly fixed with cement and create an artificial mood.

Mount Fuji, the paths and some lanterns appeared to have been vandalized.

Our data suggest that the Japanese garden is not attended for leisure purpose, but to gain knowledge, especially in relation to the animals in the zoo and not to the Japanese garden itself, since the vast majority (88\%) did not know the history and fundamentals of the Japanese garden, and the majority of adults (34\%) used the visit for taking the children to the zoo. So, the Japanese garden of Ribeirão Preto has fulfilled one of its main functions, which is the contemplative leisure.

Thus, it is important to disclose the history, functions of plants and architectural elements in the Japanese garden, through newsletters and trainees.

\section{CONCLUSION}

The Japanese Garden of the Fábio Barreto Municipal Forest/Zoo in Ribeirão Preto (SP), needs reform, replacement and / or introduction of some of its plants that are already adapted to the region, such as Pinus oocarpa and $P$. caribea, and typically tropical architectural elements, for being considered a typical Japanese garden.

The garden is mischaracterized in relation to style and presents maintenance problems, which requires the redesign so that the space can fulfill the purpose of promoting leisure, and bring people together for cultural, economic, political or social reasons.

\section{REFERENCES}

ABNT. Associação Brasileira de Normas Técnicas. NBR 13133: Norma de execução de levantamento topográfico. Rio de Janeiro: 1994. 35 p

BORTOLETO, S.; DA SILVA FILHO, D.F.; SOUZA, V.C.; FERREIRA, M.A.P.; POLIZEL, J.L.; RIBEIRO, R.D.C.S. Composição e distribuição da arborização viária da estância de Águas de São Pedro-SP. Revista da Sociedade Brasileira de Arborização Urbana, Piracicaba, v.2, n.3, p.32-46, 2007.

BRUMMITT, R.K.; POWELL, C.E. Authors of plant names. London: Royal Botanic Gardens, 1992. 732p.

CAMPOS, J.B.; ROMAGNOLO, M.B.; SOUZA, M.C. Structure, composition and spatial distribution of tree species in a remnant of the semi deciduous seasonal alluvial forest of the upper Paraná river floodplain. Brazilian Archives of Biology and Technology, Curitiba, v.43, n.2, p.185-194, 2000.

CARVALHO, L.M.; PAIVA, P.D.O.; COELHO, S.J.
Caracterização da Praça Dr. Augusto Silva localizada na cidade de Lavras/MG. Ciência e Agrotecnologia, Lavras, v.27, n.3, p.520-526, 2003.

CHESSHIRE, C. Creating a japanese garden. Leicestershire: Southwater, 2011b.

CHESSHIRE, C. The japanese garden. London: Lorenz Books, 2011a. 64p.

DE ANGELIS, B.L.D. A praça no contexto das cidades - o caso de Maringá, PR. 2000. 366 f. Tese (Doutorado em Geografia Humana) - Faculdade de Filosofia, Letras e Ciências Humanas, Universidade de São Paulo, São Paulo, 2000 .

DE ANGELIS, B.L.D.; ANGELIS NETO, G. de. A praça no contexto da engenharia urbana - metodologia de avaliação. Acta Scientiarum, Maringá, v.21, n.4, p.941-948, 1999.

GIMENES, R.; ROMANI, G.N.; BATISTA, G.S.; PIVETTA, K.F.L. Interpretação do uso, do mobiliário e da arborização da Praça Sete de Setembro, Ribeirão Preto, SP. Revista da Sociedade Brasileira de Arborização Urbana, Piracicaba, v.6, n.3, p.22-42, 2010.

GONG, C.F.; PARRAMORE, L. Living with Japanese gardens. Layton: Gibbs Smith, 2006. 96p.

GREY, G.W.; DENEKE, F.J. Urban forestry. New York: John Wiley \& Sons, 1986. 279p.

GUIADOS MONUMENTOS EM LUGARES PÚBLICOS. Ribeirão Preto: Prefeitura Municipal de Ribeirão Preto, 2008. Disponível em: <http://www.ribeiraopreto.sp.gov.br/ principaln.php?pagina=/scultura/arqpublico/monumentos/ i14m-59-ijapones.php>. Acesso em: 03 nov. 2011.

HORTON, A. Creating japanese gardens. Marilyn Rogers: Meredith Books, 2003. 112p.

IBGE - Instituto Brasileiro de Geografia e Estatística. Cidades@. Rio de Janeiro, 2010. Disponível em: <http:// www.ibge.gov.br/cidadesat/topwindow.htm?1> Acesso em: 27 dez. 2011.

KEANE, M.P. The Japanese tea garden. California: Stone Bridge Press, 2009. 284p.

KEANE, M.P. Japanese garden design. Boston: Charle E. Tuttle, 1996. 184p.

KETCHELL, R. Japanese gardens in a weekend. London: Hamlyn, 2005. 160p.

LEVY-YAMAMORI, R.; TAAFFE, G. Garden plants of Japan. Portland: Timber Press, 2004. 440p.

LORENZI, H. Árvores brasileiras: manual de identificação 
e cultivo de plantas arbóreas nativas do Brasil. 3. Nova Odessa: Instituto Plantarum, 2009. v. 2, 384p.

LORENZI, H. Árvores brasileiras: manual de identificação e cultivo de plantas arbóreas nativas do Brasil. 5. ed. Nova Odessa: Instituto Plantarum, v.1, 2008. 384p.

LORENZI, H.; SOUZA, H.M. Palmeiras no Brasil: nativas e exóticas. Nova Odessa: Instituto Plantarum, 1996. $303 p$.

LORENZI, H.; SOUZA, H.M.; TORRES, M.A.V.; BACHER, L.B. Árvores exóticas no Brasil: madeireiras, ornamentais e aromáticas. Nova Odessa: Instituto Plantarum, 2003. 368p.

MILANO, M.S.; DALCIN, E.C. Arborização de vias públicas. Rio de Janeiro: Light, 2000. 226p.

PAIVA, A.V.; LIMA, A.B.M.; CARVALHO, A.; JUNIOR, A. M.; GOMES, A.; MELO, C.S.; FARIAS, C.O., REIS, C.; BEZERRA, C.; JUNIOR, E.A.S.; MACEDO, E.; LIMA, E.S.; SOBRINHO, F.; SILVA, F.M.; BONFIM, J.C.; JUNIOR, L.S.; CORREA, M.; DUMONT, M.L.; JUNIOR, M.A.I.; PANTOJA, N.V.; DAVILA, R.M.; GABRIEL, R.; SILVA, R.A.; CUNHA, R.M.; OLIVEIRA, R.S.; DIAS, R.; NICHELI, S.P.; COSTA, S.; SOUZA, T.C.; PEREIRA, T.F.; CASTELO, Z.; FERRARI, F.S. Inventário e diagnóstico da arborização urbana viária de Rio Branco, AC. Revista da Sociedade Brasileira de Arborização Urbana, Piracicaba, v.5, n.1, p.144-159, 2010.

PINTO-COELHO, R.M. Fundamentos em ecologia. Porto Alegre: Artmed, 2000.

RODERJAN, C.V.; BARDDAL, M.L. Arborização das ruas de Curitiba - PR. Guia prático para a identificação das espécies. Curitiba: FUPEF, 1998. 14p.

ROMANI, G. de N. Análise quali-quantitativa da arborização na Praça XV de Novembro em Ribeirão PretoSP, Brasil. Revista Árvore, Viçosa, v.36, n.3, p.479-487, 2012.

SANTAMOUR JÚNIOR, F.S. Trees for urban planting: diversity uniformity, and common sense. In: METRIA CONFERENCE, 7., 1990, Lisle. Proceedings... Lisle: [s.n.], 1990. p. 57-66.

SAWANO, T. Creating your own japanese garden. Tokyo: Japan Publications Trading, 2008. 120p.

SILVA, A.T.; TAVARES, T.S.; PAIVA, P.D.O.; NOGUEIRA, D.A. As praças Dr. Augusto Silva e Leonardo Venerando Pereira, Lavras-MG, segundo a visão dos seus freqüentadores. Ciência e Agrotecnologia, Lavras, v.32, n.6, p.1701-1707, 2008.

SOUZA, V.C.; LORENZI, H. Botânica sistemática: guia ilustrado para identificação das famílias de Fanerógamas nativas e exóticas no Brasil, baseado em APG II. 2. Nova Odessa: Instituto Plantarum, 2008. 704p.

UNDERWOOD, P. Designing and creating Japanese gardens. Berkshire: The Crowood Press, 2005. 192p.

YOUNG, D.; YOUNG, M. The art of japanese garden. Singapore: Tuttle Publishing, 2005. 176p. 